\title{
PS Update
}

\section{ACTIVITIES}

Anita Chari, assistant professor of political science, University of Oregon, presented the book talk "A Political Economy of the Senses: Neoliberalism, Reification, Critique," with commentary by Paul Apostolidis, professor and T. Paul Endowed Chair of Political Science, Whitman College.

April Clark, assistant professor, political science, Northern Illinois University presented "Women and Politics: Engagement, Leadership and Perceptions" at Kishwaukee College, in March

E.J. Dionne, Jr., delivered the annual Manatt-Phelps Lecture in Political Science at Iowa State University, in April.

Chris Ellis, associate professor; Scott Meinke, associate professor; and Lindsay Nielson, visiting assistant professor from the political science department at Bucknell University hosted a panel discussion about the state of the ongoing elections, in March.

Krista Jenkins, professor of political science, Fairleigh Dickinson University and executive director, PublicMind, gave a series of discussions titled "American Identity and the Political Process" at the Washington Township Public Library, in Long Valley, New Jersey, throughout April and May.

Rodney Hero, Haas Chair in Diversity and Democracy, University of California, Berkeley, presented "Race, Ethnicity and (In)Equality in American Politics" at Drury University's L.E. Meador Center for Politics \& Citizenship as part of its public inaugural speaker series, in February.

Mary Rose Kubal, associate professor, political science, St. Bonaventure University, gave a lecture, "The Hillary Paradox: What Can (and Can't) the Career of HRC Tell Us about the Past, Present, and Future of Women in Politics" at the Olean Public Library of St. Bonaventure, NewYork, in March.

At University of California, Berkeley, Gabriel Lenz, associate professor of political science; Paul Pierson, professor of political science; and Eric Schickler, professor and department chair of political science, discussed the dynamics of the 2016 presidential election contest during a presentation in April.

Michael S. Lewis-Beck, F. Wendell Miller Distinguished Professor of Political Science, University of Iowa, presented "US Presidential Election Forecasting: A Look at 2016" in May.

Daniel Magleby, assistant professor, political science, Binghamton University, presented "Can Gerrymanders be Measured?" at Washington University, St. Louis, in April.

Banks Miller, associate professor, political science, University of Texas, Dallas, gave a talk about immigration, judges, and US asylum at University of California, Riverside, in March.

Melissa Miller, associate professor, political science, Bowling Green State University, presented a public talk about money's influence in politics, hosted by the League of Women Voters of Bowling Green, in March.

Elin Naurin, associate professor, department of political science, University of Gothenburg presented "Do parties keep their election promises?" at Washington University, St. Louis, in April.

Cary J. Nederman, professor of political science, Texas A\&M University, presented a public lecture "The Multiple Meanings of the Magna Carta in the Long Fourteenth Century," at University of Louisiana, Lafayette, in April.

David Robertson, Curators' Teaching Professor of political science at the University of Missouri, St. Louis and the 2016 Maxwell C. Weiner Distinguished Professor of Humanities at Missouri University of Science and Technology, presented "State and Landscape: The American Environmental Constitution," in April.

Gary Schaub, Jr., Centre for Military Studies, University of Copenhagen, represented the Royal Danish Air Force at the NATO Joint Air Power Competence Centre Think Tank Forum, Madrid, Spain, in April 2016.

Karen Sebold, assistant professor, political science University of Arkansas, presented "From Watergate to TrumpMania: Lessons I Have Learned in Life from Presidential Politics" for the The Mortar Board National College Senior
Honor Society's annual Last Lecture Series.

At Yale University Ian Shapiro, Henry R. Luce Director of the MacMillan Center and Sterling Professor of Political Science, moderated a panel, "Refugees, Forced Displacement, and Humanitarian Responses," comprised of panelists Jason Lyall, associate professor of political science; Mushfiq Mobarak, professor of economics; Catherine Panter-Brick, professor of anthropology; and Margaret Peters, assistant professor of political science. The public panel was part of an event to highlight the MacMillan Center's 1oth anniversary.

Theda Skocpol, Victor S. Thomas Professor of Government and Sociology and American Politics, Harvard University, and A.D. White Professor-atLarge, Cornell University presented the free public talk "The Koch Effect: The Impact of a Cadre-Let Network on American Politics and Public Policy" at Cornell University, in April.

Valerie Sperling, professor, political science Clark University, presented a public lecture "Sex, Politics, and Putin: Masculinity and Russian Foreign Policy," at the Warren Hunting Smith Library in Geneva, New York, in March.

Natalie Fuehrer Taylor, associate professor of government at Skidmore College, presented "The Sisterhood Is Powerful, But Is It Global? Feminism at Home and Abroad" at the Helen DeVos College of Education at Lee University, in March.

\section{AWARDS}

Richard Aidoo, associate professor, political science, Coastal Carolina University, Edwards College Distinguished Scholarship Award

Linda L. M. Bennett, president, University of Southern Indiana, received the 2015 Rotary Civic Award from the Rotary Club of Evansville, Indiana. The award is given to recognize outstanding civic, charitable, humanitarian, and/or cultural services to the City of Evansville and its people.

DeLysa Burnier, professor, political science, Ohio University, received the 2016 Rita Mae Kelly Award for Distinguished Research on Women's Issues from the Section for 
Women in Public Administration/ American Society for American Public Administration.

Sandra Botero Cabrera received the 2016 dissertation prize from the Law and Society Association, for her dissertation "Courts That Matter: Judges, Litigants, and the Politics of Rights Enforcement in Latin America."

Courtenay Daum, associate professor, political science, Colorado State University, Ann Gill Excellence in Teaching Award

Megan DeMasters, Colorado State University, College of Liberal Arts Excellence in Teaching Award for Graduate Teaching Assistants

Joseph Fitsanakis, associate professor, political science, Coastal Carolina University, Edwards College Apple Award for teaching

Leila Kawar, University of Massachusetts Amherst, received the Herbert Jacob Book Award for her book Contesting Immigration Policy. The award recognizes the best book in Law and Society scholarship published in 2015.

Rick Kilroy, associate professor, political science, Coastal Carolina University, Edwards College Distinguished Service Award

Nukhet Sandal, assistant professor, director, War and Peace Studies Program, Ohio University, Jeanette G. Grasselli Brown Teaching Award in the Social Sciences

Matthew Schmidt, assistant professor of political science, University of New Haven, UNH Award for Excellence in Experiential Education

Gisela Sin, associate professor, University of Illinois, Urbana-Champaign, 2016-2017
Clarence A. Berdahl Award for

Excellence in Undergraduate Teaching

Amy Smith, assistant professor, political science, Iowa State University, was awarded a visiting fellowship with the Kellogg Institute for International Studies at the University of Notre Dame, where she will continue developing her manuscript "The Culture Wars in Another America: Evangelicals, Catholics, and Brazilian Democracy."

John Straayer, professor of political science, Colorado State University, Distinction in Advancement Award

Rebecca Thorpe, assistant professor, political science, University of Washington received the D.B. Hardeman Prize for her book The American Warfare State: The Domestic Politics of Military Spending. The award is given by the Lyndon Baines Johnson Foundation for the best book on the US Congress.

\section{APPOINTMENTS}

Lara Brown, interim director, Graduate School of Political Management, George Washington University

Tim Büthe, associate professor of political science and public policy, Duke University, has been appointed a lead author for "Varieties of Global Governance" chapter of the report of the International Panel on Social Progress (http://www.ipsp.org/). The IPSP, a multidisciplinary initiative that involves about 250 scholars, is tasked to develop "research-based, multidisciplinary, non-partisan, actiondriven solutions to the most pressing challenges of our time."
Kerwin Charles, Edwin and Betty L. Bergman Distinguished Service Professor and deputy dean, Harris School of Public Policy, University of Chicago, was appointed interim dean of the Harris School of Public Policy.

Paul F. Diehl, associate provost, director of the Center for Teaching and Learning, and Ashbel Smith Professor of Political Science at the University of Texas, Dallas, formerly Henning Larsen Professor of Political Science at the University of Illinois

Hahrie Han, Anton Vonk Associate Professor of Environmental Politics, University of California, Santa Barbara

Srividya Jandhyala, assistant professor, ESSEC Business School, Singapore and Anastassia Obydenkova, senior researcher, Higher School of Economics, Moscow, Russia were among the six scholars named as Fung Fellows at Princeton University. Christina Davis, professor of politics and international affairs, Princeton University, will serve as director of the year-long program administered by the Princeton Institute for International and Regional Studies.

Muqtedar Khan, professor, political science and international relations, University of Delaware

Nicholas Sambanis, Philip R. Allen Professor of Political Science, Yale University

Rick Travis, professor, political science, Mississippi State University, interim dean, College of Arts and Sciences

\section{RETIREMENTS}

Steven Schier, Dorothy H. and Edward C. Congdon Professor Political Science, Carleton College 